Fashion Theory

The Journal of Dress, Body and Culture

ISSN: 1362-704X (Print) 1751-7419 (Online) Journal homepage: http://www.tandfonline.com/loi/rfft20

\title{
Constructing and Representing the Islamic Consumer in Turkey
}

\section{Özlem Sandıkcı \& Güliz Ger}

To cite this article: Özlem Sandıkcı \& Güliz Ger (2007) Constructing and Representing the Islamic Consumer in Turkey, Fashion Theory, 11:2-3, 189-210, DOI: 10.2752/136270407X202754

To link to this article: http://dx.doi.org/10.2752/136270407X202754

Published online: 21 Apr 2015.

Submit your article to this journal $₫$

Џlll Article views: 172

Q View related articles $\sqsubset$

Citing articles: 45 View citing articles 5 


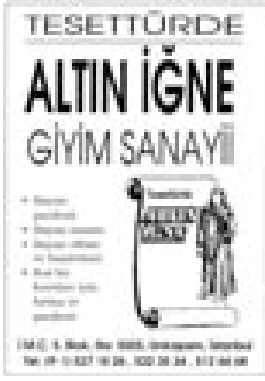

Constructing and Representing the Islamic Consumer in Turkey

Özlem Sandıkcı is an assistant professor of Marketing at Bilkent University, Turkey. Her current research interests include fashion consumption, consumption rituals and space-consumption interactions.

sandikci@bilkent.edu.tr

Güliz Ger is a professor of Marketing at Bilkent University, Turkey. Her research addresses global-local encounters and deals with various issues of consumption, marketing, and development in transitional societies. ger@bilkent.edu.tr

\section{Abstract}

This study looks at how marketers in Turkey construct and represent tesettürlü consumers (women wearing Islamically inspired forms of covered dress) in advertising and other commercial imagery, and how these representations are shaped and transformed by the local and global dynamics of consumerism, capitalism, and politics. We believe that the emergence of tesettürlü women as a distinct consumer segment and their evolving representation in the marketing imagery are revealing of the processes of identity formation and negotiation as well as the social changes that have been occurring in Turkey since the 1980s. 
By attending to the discourses and practices of market actors, namely companies and designers that manufacture and sell clothing and related products to tesettürlü women in Turkey, we show how the Islamic fashion industry operates through a play on cultural difference and similarity, and fabricate the ideal of a "modern" tesettürlü woman which is attainable through consumption.

\section{KEYWORDS: headscarf, advertising, fashion, Islam, Turkey}

One of the fundamental ways the global consumerist ethos circulates and reproduces itself is through commercial imagery. Advertising, marketing, fashion, and media construct and disseminate aestheticized and stereotyped images of the modern consumer. Who is represented and how they are represented in commercial discourse suggests identities that are legitimized and privileged over other identity formations. As Schroeder and Zwick argue, "advertising representations influence cultural and individual conceptions of identity, and must be understood as the result of changing social and cultural practices" (2004: 24). While there is a wealth of literature dealing with the nature and politics of advertising imagery (e.g., Goffman 1979; Goldman 1992; Leiss et al. 1986; Williamson 1978), there is little written on how these images come into existence and change over time as a result of social, cultural, political, and economic factors.

This article looks at how marketers in Turkey construct and represent the tesettürlü consumer in advertising and other commercial imagery, and how these representations are shaped and transformed by the local and global dynamics of consumerism, capitalism, and politics. We believe that the emergence of tesettürlü women as a distinct consumer segment and their evolving representation in marketing imagery reveal the processes of identity formation and negotiation as well as the social changes that have been occurring in Turkey since the 1980s. By attending to the discourse and practices of companies and designers that manufacture and sell clothing and related products to tesettürlü women in Turkey, we show how the Islamic fashion industry plays on cultural difference and similarity and fabricates the ideal of a "modern" tesettürlü woman that is attainable through consumption.

The issues of who is represented and how become critical in the case of Islam and fashion where conventional images of the veiled Muslim woman almost always take the form of the oppressed, the non-modern, the politically threatening or the exotic Other. In contrast to these stereotypical images, contemporary commercial representations of tesettürlü women in Turkey portray a modern consumer who actively seeks a fashionable and chic look and draws upon multiple cultural references and resources while constructing her identity. Previous studies detail the emergence of a prolific Islamic consumptionscape in Turkey in the last decade and indicate that consumerist ideology has 
become particularly visible in the domain of fashion (K1liçbay and Binark 2002; Sandikc1 and Ger 2001, 2002, 2005; Navaro-Yashin 2002). These studies trace changes in the meanings and practices of tesettür, and in particular the headscarf; they discuss various aspects of tesettür fashion, such as the fashion shows organized by prominent tesettür companies (Navaro-Yashin 2002) or the symbolism of tesettür clothing advertisements (Kılıçbay and Binark 2002). Yet, research seldom notes the complex and multidimensional processes underlying the formation and evolution of the market for tesettür fashion and the roles the fashion industry plays in shaping consumer identities. Studies of dress and fashion, we believe, should also address market dynamics and the constitution of people as consumers.

Religion affects marketplace activities. Religious traditions and institutions can influence the rules of trade, prohibit or obligate the trade of certain products, and affect the time and place of markets (Mittelstaedt 2002). Spiritual practices and beliefs translate into demand for certain goods and services; markets develop to meet the demand. Market forces, however, also affect religious identities and practices. Through political, institutional, moral, and competitive mechanisms, markets can influence the parameters of religion and force organizations to negotiate being faithful and competitive, and believers to reevaluate what it means to be faithful. What are traded in the marketplace today are not only the products themselves but also their meanings and lifestyle connotations. Contemporary marketing, as a discourse and practice, deals with imagining, representing, and constructing identities that will appeal to the target consumers. As Davila, in her study of the Latino market in the USA, argues "the reconstitution of individuals into consumers and populations into markets are central fields of cultural production that reverberate within public understanding of people's place, and hence of their rights and entitlements, in a given society" (2001: 2). Analysis of the discourses and practices of marketing agents, therefore, helps us better understand social and institutional conceptions of identities in a particular society at a particular time.

Our study draws from data collected through ethnographic work conducted over a period of four years in Turkey. These include in-depth interviews with owners and personnel of clothing stores catering to tesettürlü women in Ankara and Istanbul; observations at numerous fashions shows, shopping centers, and hotels; collection of news stories and articles that have appeared in the media; and a visual archive of pictures taken by us as well as pictures circulating in the media, advertisements, and company catalogs. Throughout the project, we relied upon several assistants to enlarge our circle of contacts and spaces observed. We also employed a tesettürlü sociologist to gain access to the circles from which we were excluded. 


\section{The Meeting of Tesettür and Fashion in Turkey}

Since the late 1970s, the so-called Islamic resurgence has become a major social and political force impacting the Muslim world and beyond. During the last two decades, the role of Islam in Turkey has also changed considerably and Islamic actors have gained significant political and economic power (Demir et al. 2004; Göle 2000). As the polarization between the so-called Islamists ${ }^{1}$ and secularists intensified during the mid-1980s, head covering changed from a traditional and/ or spiritual act into a political performance. The distinction between traditional/spiritual and political Islam, which found its expression in the style of headdress, was representative of the contrasting background, education, public participation, and militancy of the women who cover their hair. Many rural, elderly, and traditional Muslim women covered their heads using a başörtüsü, a scarf that is tied casually and covers only the head, but not the neck and may show some of the hair. However, it was primarily the young, urban, and educated women who wore the türban, a scarf that covers the hair and the neck completely and is tied in a particular manner (Figure 1). By the early 1990s, the türban and the long, loose overcoat accompanying it had become the symbol of political Islam. For the secular public, the turbaned woman represented the frightening cultural Other who threatened the modern, urban, Western lifestyle. In an attempt to contain the threat, the ban on wearing religiously inspired clothing in schools and state offices was strictly enforced; this led to frequent clashes between police and turbaned women, protesting in front of universities and state offices.

However, along with the politicization of Islam, the 1980s and 1990s also witnessed the emergence of an Islamic consumptionscape in Turkey. Indeed, as Navaro-Yashin observes "the rise of the Islamist movement in popularity and power is indissoluble from the development of specialized businesses for 'Islamic goods' and the formation of market networks for believers" (2002: 223). Many factors contributed to the development of the Islamic consumptionscape. During the 1980s and 1990s, the Turkish economy went through an extensive restructuring program and adapted neo-liberal policies that opened it up to global forces. This was followed by the typical effects of liberalization: the proliferation of foreign brand-name products, the emergence of new spaces for shopping and entertainment, the growth of the advertising industry, and the development of a consumption-oriented urban middle class. However, it was not only the secular urban middle/upper classes whose lives were changed. As wealth accumulated among particular sections of the Islamic population, a bourgeoisie, conservative in values but avant-garde in consumption practices, began to emerge. Just as the secular upper classes developed a taste for bourgeois consumption, so did the religious upper classes (Sandıkcı and Ger 2002). 
The growth of the Islamic bourgeoisie coincided with the development of Islamic capital and markets during the 1980s and 1990s. Hoping that economic development would be fueled by small- to mid-size exportoriented companies, the governments supported local entrepreneurs of the religious cities of Anatolia, encouraging them to develop their businesses. Backed also with international capital, coming mainly from other Muslim countries as well as from Turkish workers living in Europe, Islamic businesses progressed rapidly and began to compete in almost all the sectors of the economy. Adopting the logic of contemporary capitalism, the religious and conservative small-scale rural businesses grew into bigger companies operating in the cities. These businesses created not only an alternative market for those who were religious but also a consumer segment that had money to spend in these markets. As Islamic capital grew, a new style of consumption emerged in every domain of life. Soon a wide variety of products positioned as "Islamic," ranging over Summer resorts, clothing, decorative objects and food, became available to the newly emerging, religiously oriented middle/ upper classes.

Interestingly, as the market grew, it began to attract the attention of multinational companies. For example, in July 2005 Colgate Palmolive introduced misvak-flavored toothpaste to the Turkish market. Misvak is a stick of wood taken out of the toothbrush tree and beaten into fibers at one end to be used as a toothbrush. Before the advent of toothpaste and toothbrushes, people in the Middle East used misvak to clean their teeth and freshen their breath. According to the Muslim faith, because it was used by the prophet, cleaning the teeth with misvak is regarded as part of the sunna. ${ }^{2}$ Preceding the launch of Colgate's version, Indonesian brands of misvak toothpaste were already available in the open markets. Colgate's entry however, with significant advertising support, put misvak under the spotlight, creating a debate over its use. Company officials claim that misvak is a natural ingredient whose benefits have been known for centuries. The Istanbul Dentists' Association simply dismisses this claim. According to their spokesperson, there is no scientific evidence indicating that misvak enhances the toothpaste's cleaning power; they say, rather, "this is a product aimed to appeal to the religious segment" (quoted in Ersoy 2005).

The growing importance of consumption as a lifestyle marker among the religious middle/upper classes suggests a new phase of the Islamic identity, one that is not confined to revolutionary politics only (Göle 2002). With more money, power, exposure to local and international urban lifestyles, and experience in the public sphere, Islamic consumers and marketers blend into and negotiate the modern capitalist life. The acquisition of consumption and marketing skills and the increasing interaction between religious and secular markets are no better exemplified than in the domain of tesettür fashion. An inevitable outcome of the rise of political Islam has been the growing demand for 
headscarves, overcoats, and other clothing items and the subsequent development of a business sector to meet this demand. In the Unkapan district of Istanbul, for example, an entire shopping center, catering only to the covered women, was already established by the mid-1980s. In subsequent years, similar shops emerged in other cities. Many of these stores adopted names that evoke Islam, such as "Tevhid" (unity under one God), "Ihvan" (Muslim brotherhood), and "Hak" (one of the names of God) and came to be known as tesettür stores.

As the market for tesettür clothes expanded, the industry developed from small ateliers to national and international companies offering outfits and headscarves made out of a range of fabrics, in a variety of cuts, shapes, and colors, and sold at a spectrum of prices. The initial uniformity of the dressing style gradually gave way to more heterogeneous styles, signaling a rising fashion consciousness especially among the middle-/upper-class, urban, well-educated, younger religious women. Tesettürlü women wearing smaller headscarves and tighter and shorter coats, skirts, pants, and jackets in brighter and trendy colors began to populate the streets. By the end of the 1990s, the large headscarf and the long, loose overcoat, which had emerged as the symbol of political Islam, seemed to have migrated to the squatter areas, their symbolism limited to the urban poor. At the same time, a multitude of styles of clothing and ways of tying variously shaped and sized headscarves have developed as markers of taste, difference, and social position among the urban upper classes. Tesettür has met fashion.

\section{Tesettürlü Women in the Marketing Imagination}

In 1992, Tekbir Giyim, a prominent tesettür company operating since 1982, organized the first ever tesettür fashion show in Turkey. The show featured famous Turkish models who normally show underwear, swimwear, and Western-style clothes to the secular upper classes. Fully made-up and as attractive as ever but with heads covered, the models walked down a runway animated by artificial clouds, projecting lights, and music to present the company's collection of suits, dresses, overcoats, and eveningwear. The event immediately caused controversy among both the Islamic and secular public, interestingly for almost the same reasons.

For the religious opponents, the fashion show was antithetical to the principles of Islam and Islamic veiling. Fashion shows, as they point out, are an instrument of capitalism, designed to motivate people to consume more. Tesettür, on the other hand, is about modesty and, they argue, should not be abused as a marketing tool. Moreover, the principle of display, on which fashion is based, is perceived to be against the core purpose of tesettür, which is to avoid the male gaze. For many secularists, the Tekbir show was equally disagreeable. Tesettür could 
not be related to fashion; it was inconceivable that a tesettür company could organize a fashion show and seek publicity. Tekbir was accused of exploiting religion for commercial purposes; its employment of top models who are not normally covered and who had quite promiscuous lifestyles was regarded as a sign of fraudulence. And most of all, the clothes were judged to be too pretentious, too distasteful, and too outof-fashion.

Despite the controversy, Tekbir continued to organize fashion shows (for a detailed discussion of the November 1994 show, see NavaroYashin 2002) and a few other companies followed in its footsteps. No doubt, the shows as well as the controversy they caused were beneficial to the company as they generated free publicity and helped Tekbir achieve high brand-name awareness in a short period of time. Beyond sparking debate about the fashion and politics of tesettür, Tekbir's 1992 show was an important step in the marketing of Islamic-style clothing. Until then such clothing was advertised in media that appealed only to the target segment, that is, tesettürlü women; it would have been difficult for the secular public to be exposed to these commercial messages. The Tekbir show, however, not only made tesettür commercially visible but also it framed it as fashion. The coming together of Western capitalism and Islamic ambitions highlighted a new understanding of tesettür, which is firmly grounded in the discourses of marketing and consumption.

Kılıçbay and Binark (2002) consider the 1992 Tekbir show to be the marker of a new phase of fashion in veiling for Turkey. They maintain that during the 1980 s, companies sought to appeal to tesettürlü women by referring to the religious and political meanings of covering. According to the authors, early advertisements lacked some essential features of fashion advertising, such as the face of the model; they limited their message to information about company names, distribution addresses, and product types. The second phase, however was "characterized by concern with creating marketing strategies such as brands and images" (Kıliçbay and Binark 2002: 504). Featuring real woman with various status symbols, such as cellphones and camcorders, these advertisements, Kilıçbay and Binark argue, "invite consumers to be different from others" (2002: 504), namely from those who are not covered or who are traditionally covered.

There is no doubt that the advertisements of tesettür companies have changed over the years; they have developed from simple product announcements to sophisticated lifestyle representations. Missionary statements about tesettür gave way to lifestyle depictions; crude visuals were replaced by professional fashion photography; visuals replaced text. This, however, has not been merely an evolution in style, a move from rational to emotional advertising. Underlying it has been a change in the mode of address, a transformation of the subject to whom the marketers of these clothes seek to appeal. Unmistakably apparent in these representations is a gradual shift from the image of a "pious 
woman" to the image of a "modern consumer." However, it has not been the case that one image replaced the other entirely; rather, commercial representations have proliferated along with the fragmentation of a seemingly unified Islamic identity at the sociopolitical level.

What appears as an immediately visible distinction between the "pious woman" and the "modern consumer" is their play on difference. Whereas the former rests on a claim to be different from the heathen seculars, the latter highlights similarity between the two groups. Obviously, difference and similarity are relational and need their referents to provide a meaningful association. The referent for the "pious woman" takes the shape of the uncovered and/or traditionally covered woman; the one who is negatively valued and kept at a distance. For the "modern consumer," however, the referent emerges as the uncovered but fashionable Western-looking woman, the one who is to be emulated.

The commercial representations of the "pious woman" emphasize the moral necessity of covering for woman; in doing so, they set the boundaries of both religiosity and femininity. The "pious woman" emerges as someone who is courageous and committed enough to look different from uncovered or traditionally covered women because she wears tesettür clothes. Her femininity requires her to cover and her covering confirms her conviction. See, for instance, the advertisement of Ceran Manifatura (Figure 2). The advertisement is almost all text except for two small illustrations of women wearing black chadors. Various pieces of text located haphazardly in different sections of the advertisement repeat the call for covering: "Tesettür is not tradition but an order of God." "Tesettür and headscarf are the symbols of a Muslim woman and they are the clothing style that God ordered and the family of the prophet practiced." "Tesettür is the symbol of a woman's modesty." Blurring the boundaries between propaganda and advertising, the advertisement first promotes the notion that covering is obligatory, then it promotes the products that help fulfill that obligation.

The "pious woman," however, appears to be devoid of individual identity. In some advertisements, the face of the model, real-life or illustration, is literally absent. The face is either camouflaged by a black or white space (Figure 3) or chopped out altogether (Figure 4). As Kilıçbay and Binark (2002) point out, the absence of the face might be related to the worry about concealing female sexuality in Islam. However, we believe there is a more disturbing aspect to this absence: it represents a deliberate act of silencing that erases subjectivity altogether and ascribes anonymity to women. The women depicted in these advertisements appear to be freestanding objects, isolated from their environment. The abstraction of the social and material world constructs the female as any female. Given the lack of representational cues, the audience can neither decode nor imagine the model's socioeconomic background, lifestyle, and aspirations; the pious woman remains unidentifiable. Religiosity 


\section{Figure 2}

Advertisement of Ceran Manifatura, c. 1990.

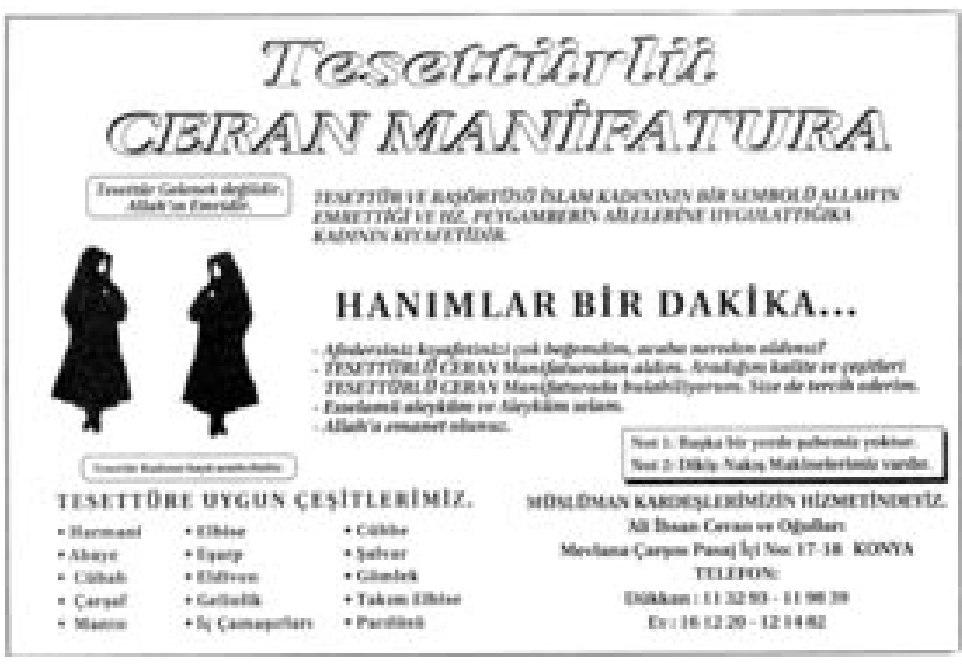

operates as an equalizing and homogenizing factor that dissolves individual identity within a uniform and anonymous Islamic identity.

But uniformity is difficult to maintain. While religious identity enables a woman to differentiate herself from "less" religious others, it alone is not enough to create distinction among those who are similar. Goods are always used to demarcate social relationships and hierarchies and this has also been the case with the headscarf and tesettür clothes. As wealth began to accumulate among the Islamic upper classes, the classificatory and discriminatory potential and uses of consumption began to become more prominent than its homogenizing and equalizing uses. Over time, the clothing styles of urban middle-/upper-class tesettürlü women have become more sophisticated and refined. Hermès and Burberry scarves, color-coordinated with clothes and shoes, are tied in modern/sporty or fancy asymmetric styles and clipped with Italian brooches, depending on the occasion (see Sandikcı and Ger 2005 for a discussion of the types and materiality of scarves). Long transparent shirts over tight tops and trendy brand-name handbags, spiky pointed-heeled shoes, and accessories became markers of status and taste. Tesettürlü women demanded to feel and look fashionable.

In an interview published in Milliyet, a high-circulation secular newspaper, Rabia Yalçın, the self-acclaimed "Islamic haute couture" designer, welcomed the coming of the Islamic bourgeoisie whom she defined as avid practitioners of conspicuous consumption (Atay 2003). She stated that covered women also feel the need to be admired; she summarized her fashion philosophy as "designing clothes that make people say 'what a beautiful woman' rather than 'what a beautiful dress" (Atay 2003). She was certainly not alone in her aspirations. According to Nur Yerlitaş, another designer, the clothes that covered 


\section{Figure 3}

Advertisement of Altın Ĭğne, $c$. 1990.
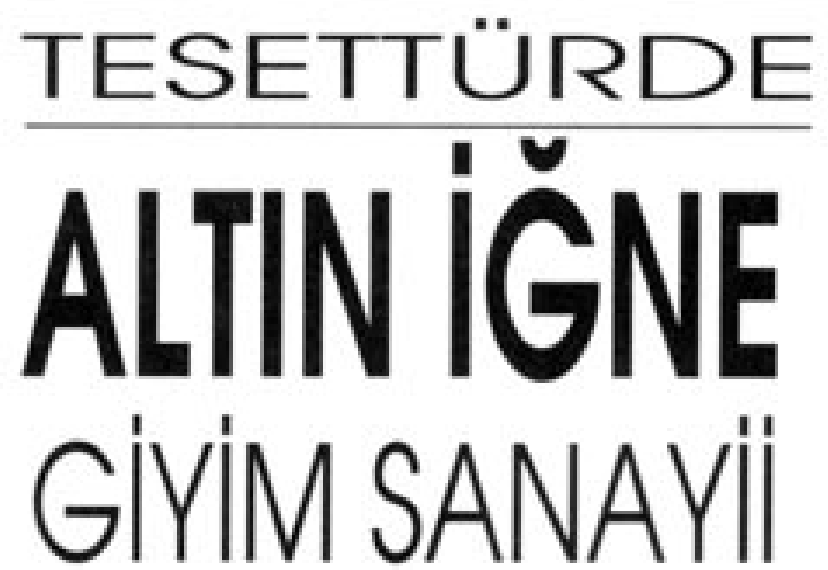

- Bayan pardesü

- Bayan manto

- Bayan elbise ve bașôrtũsũ

- Kur'ân kurslar için forma ve pardesũ

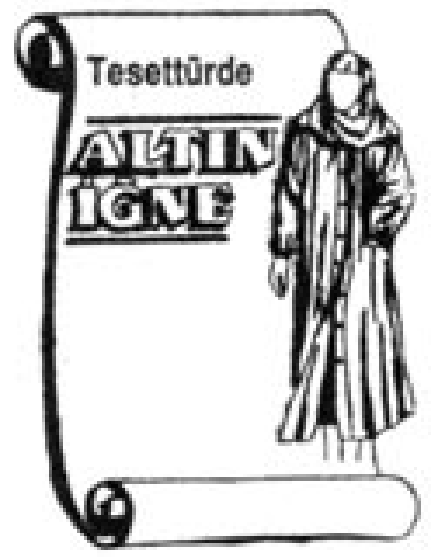

I.M.C.. 5. Blok, No: 5555, Unkapanı, İstanbul Tel: $(9-1) 5271826,5223534,5126668$

women wear now have become much more sensational and glamorous than five years ago: "Tesettürlü women are now more elaborate, eclectic, and exploratory in their dressing style. Their headscarves are more striking, their jackets, pants, and blouses are more elegant. They are much more ostentatious than uncovered women" (Engin 2004). Most striking in these accounts is not so much the changes in tesettür style but the language in which tesettür is articulated and discussed.

However, the framing of tesettür within the language of fashion, lifestyle, and choice also necessitates a mode of marketing communication that verifies and circulates the new meanings of covering. The "pious woman" with her commanding, unassuming, and visually unflattering 
Figure 4

Tuğba, Spring/Summer 1999 catalog.

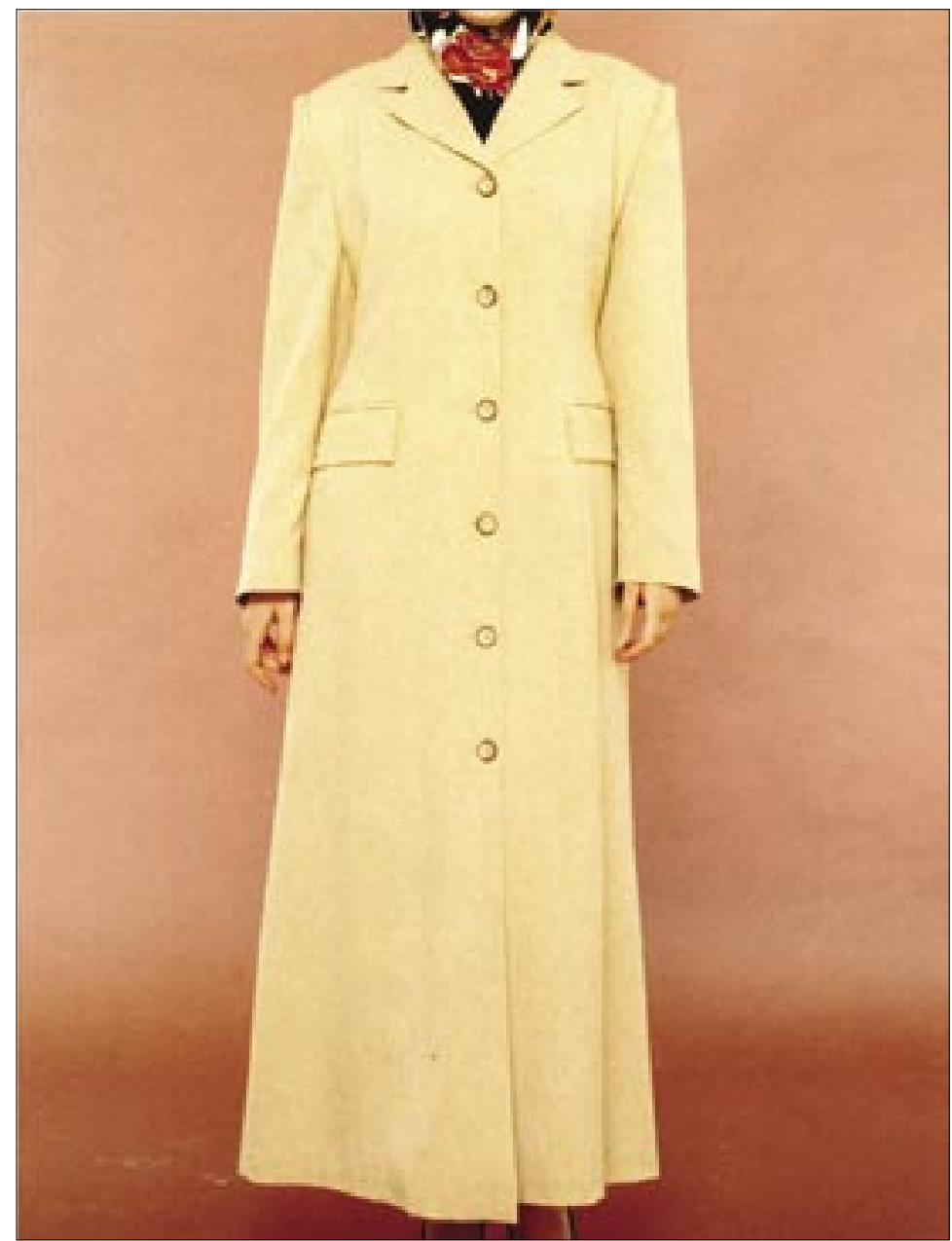

posture stands as the antithesis of the subjectivity that fashion and conspicuous consumption call for. Fashion advertising, after all, is about glamour and beauty and it encourages the prospective buyer to think of herself in terms of an image of who she can be. The image of the "pious woman" offers neither glamour nor beauty and lacks the aesthetic appeal that advertising employs to draw people into the lifestyles that it promotes. In contrast to the subdued image of the "pious woman," representations of the tesettürlü woman as the "modern consumer" highlight her aestheticized look. While the "pious woman" is appealed to by indoctrination, the "modern consumer" is seduced through the beauty of covering.

The emphasis on the beauty and aesthetics of tesettür indicates a different conceptualization of the target consumer; a woman who is 
defined more by her taste and less by her religiosity. Religiosity equalizes and homogenizes the Islamic identity; taste classifies it. Compare, for example, the advertisements discussed above to the Setre advertisement (Figure 5). "You are as free as you can dream," reads the tagline, which repeats itself alternately in Turkish and English across the two-page spread. In the middle section, a young female wearing a red jacket and pants, stares at the viewer; the red white and black headscarf and the black, pointed, high-heel shoes harmoniously complete her look. On the right side, we see her adjusting her trendy sunglasses, this time, wearing a red overcoat. In both images, she demonstrates an elegant, coordinated, and much worked-on style. The illustration is part of the company's 2004 catalog, which greets the consumer on its first page with the phrase "a brand new adventure." On each page one indeed comes across a professionally presented, stylish consumption adventure that promises the same as what any fashion advertisement promises.

It is well documented that beauty and fashion ideals have become the dominant images of femininity in advertising and woman are generally represented as objects of desire (Berger 1972; Goffman 1979; Williamson 1978). Fashion photography, in particular, emphasizes the voyeuristic gaze, perpetuating stereotypical gender roles. The puzzling element of the Setre advertisements has less to do with the eroticism of the images than with their "narcissistic display" (Mort 1988). The images accentuate the pleasures associated with dressing and grooming the body and turn the women into bodies to be looked at. But if tesettür is about avoiding the male gaze, how can we explain the images in the Setre catalog, which demand to be gazed at and admired? The Setre catalog and other similar ones suggest a recent trend in tesettür advertising that signals the mainstreaming of the Islamic identity. The references to stereotypical representations of femininity enable these images to be read within the "normalized" parameters of female identity and the codes of Western fashion. With the emphasis on similarity rather than difference, the advertisements have been transformed into conveyors of "positive" images about tesettürlü women; they seek to not only decrease fear among the secular population but also to instill self-confidence in covered women who can proudly claim that they look as fashionable and attractive as uncovered women. Paradoxically, while trying to challenge the stereotype of the covered woman as "threatening," and "unfashionable," tesettür fashion marketers reproduce another set of stereotypes, one that constructs female identity in terms of beauty, attractiveness, and sexuality. Femininity, one of consumer capitalism's most used marketing tools, continues to sell commodities-be it cars or headscarves. 


\section{Figure 5}

Setre, 2004 catalog.

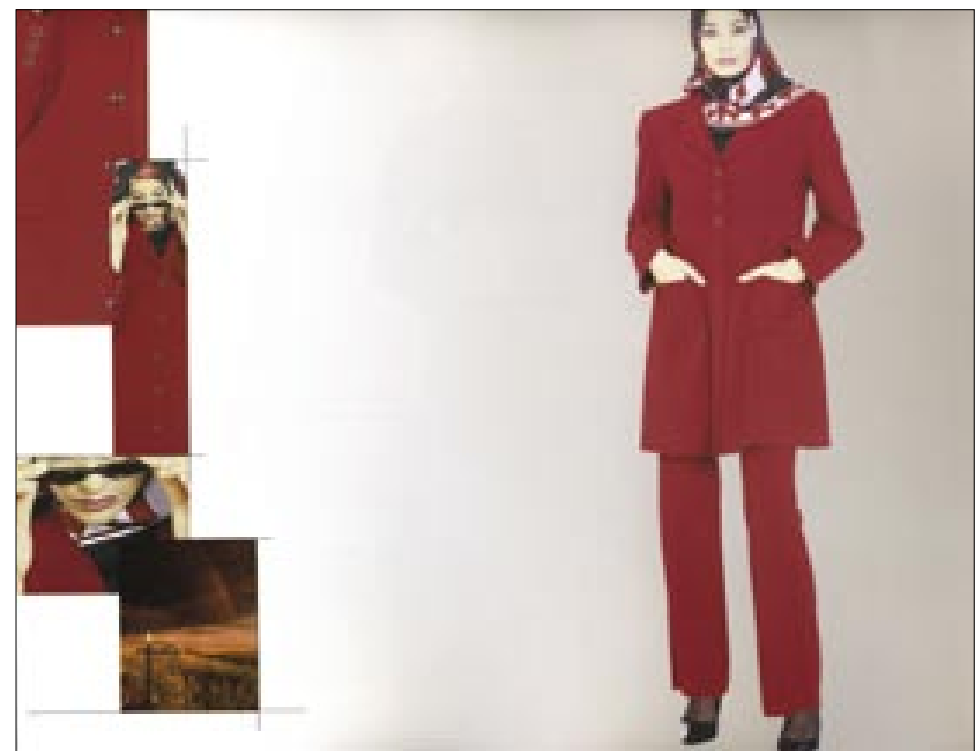

\section{International Influences and the Embeddedness of the Market}

From a marketing perspective, the transformation of the representations of tesettürlü consumers can be read as a sign of market maturation. At the early phases of market development, market agents are interested in generating primary demand for their products. That is, they seek to convince the consumers to increase their consumption of a particular product, before they start competing for brand share. Thus, we may argue that during the 1980s and early 1990s, tesettür companies were trying to establish demand for such apparel and were less interested in differentiating their brand names. Once the demand was established, competition intensified and companies began to appeal to their consumers through different lifestyle promises associated with particular brand names.

Tesettür marketers repeatedly justify the changes in their collections, advertising styles, and marketing activities with the argument: "we are responding to the changing demands of the covered women who now want to look as beautiful as their uncovered counterparts." The underlying logic of a liberal market economy notwithstanding, this explanation is indicative of a learning process, an acquisition of the skills of modern marketing. As we well know by now, "markets do not already exists 'out there' in social reality but are 'constructed'" (Sinclair 1987: 97) through the ways consumers are segmented and addressed. The development of tesettür as a market segment suggests that, over 


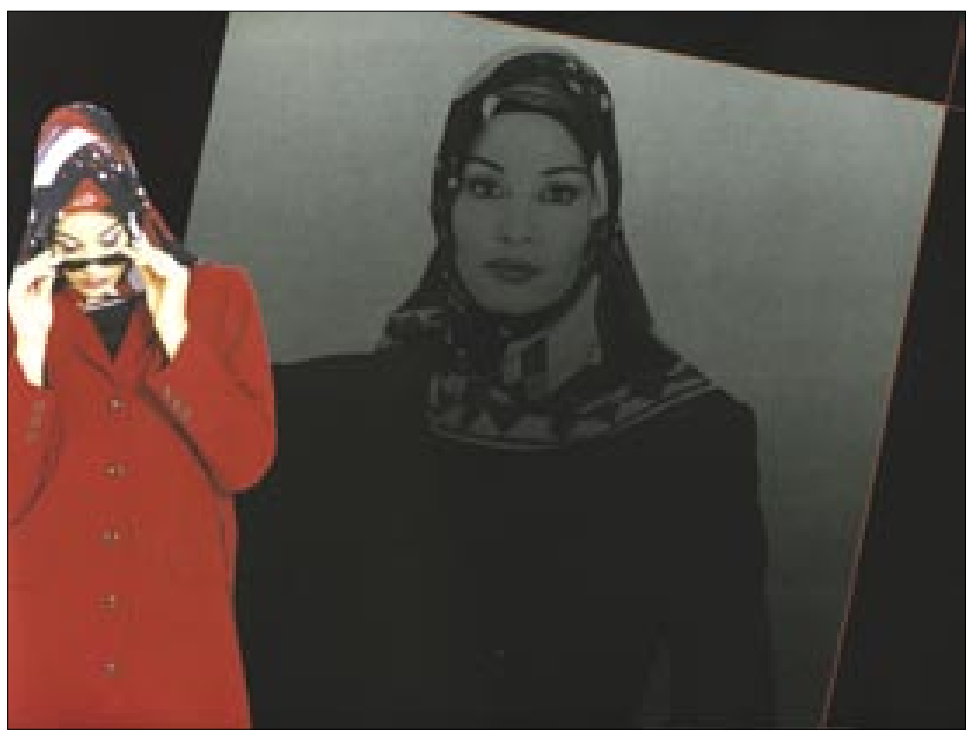

time, tesettür marketers learnt to be "better" marketers: better in terms of identifying new needs, designing products, and communicating with consumers. And covered women learnt to be "better" consumers: better in terms of demanding new products, crafting their identities through consumption, and competing in the status game.

Nonetheless, market action takes place in institutional contexts and market institutions "are shaped by legal, political and conventional constraints that are not always designed with economic outcomes in mind" (Slater and Tonkiss 2001: 116). For example, the ban in Turkey on wearing the headscarf in public spaces, such as universities and state offices, has had an impact on the design and advertising of headscarves and tesettür clothes. The ban was more strictly enforced after the army's ultimatum to the government on February 281997 regarding the increasing threat of fundamentalist activities. This quickly triggered a visible change in the dressing style of the covered women. The events of 9/11 had a further impact on the sense of tesettür fashion in Turkey. As the media repeatedly circulated stigmatizing images of Muslims highlighting the veil and the beard as symbols of Islamist militancy, it became even more important to portray a pleasant, elegant, and modern appearance. Black and dark-colored tesettür clothes and large headscarves became less popular. Perihan Mataracı, a freelance designer catering to upperclass covered women, observes, "the headscarves became smaller, overcoats became shorter, and jackets gained popularity" (quoted in Özcan and Atl 2005$)$. Prompted initially by the prohibition, and then the post-9/11 developments, the new "modern" style of covering rapidly 
spread to a larger group who did not want to appear repellent to the uncovered public or to become stereotyped as "ugly," "backward," and "threatening" (Sandıkcı and Ger 2005).

Market relations are also embedded in wider social structures, networks, and meanings that are increasingly shaped by the forces of globalization (Polanyi 1992; Zukin and Di Maggio 1990). The neoliberal policies followed by the governments since the mid-1980s have opened up Turkey to global flows of goods, capital, people, and ideas. Tesettür companies were not immune from the forces of globalization. On the contrary, those who were quick to read the changes realized the global appeal of fashion. In an interview published in a popular, secular news magazine, Mr Cafer Karaduman, one of the partners of Tekbir Giyim, outlines how the company has developed from a small manufacturer into a multinational Tesettür fashion chain:

When we began manufacturing in 1983, we were going through a period when the effects of the [1980] military coup were heavily felt. There was an authoritarian regime. We decided to produce tesettür clothes. We were not the only producer. Other manufacturers were operating as if they were the representatives of tarikats (religious sects). There were shops that were catering to the members of the tarikats they belonged to. We can characterize [Tekbir] as a company that moved out of this. We advanced from tarikats to the public. Nowhere in the world is there resistance to fashion and music. People adapt [to fashion] easily and we take advantage of this (quoted in Kas 1999).

Observing the demand for dressing in a religiously appropriate but fashionable way, Tekbir's motto became "to make covering beautiful." And this is what it did. Mixing religious aspirations with capitalist ambitions, Tekbir Giyim utilizes all the tools of fashion marketing to reach its target segment. To get inspirations for new designs, Tekbir stylists regularly visit international fashion shows and fairs. They follow Turkish, Western, and Asian fashion trends and adapt them to acceptable and desirable local styles. They regularly organize fashion shows and develop glossy catalogs. They design dresses named after famous covered Turkish women, such as politicians or the wives of political leaders; ${ }^{3}$ this helps them generate publicity. As Mustafa Karaduman, the CEO of Tekbir Giyim, acknowledges, "fashion designers are inspired by those who are under the spot light" and "items named after famous people sell better than the others" (quoted in Aktaş 2002).

As epitomized by the case of Tekbir Giyim, tesettür companies successfully adopt fashion-marketing tools and practices, follow national and international trends, and skillfully integrate them into their collections. They penetrate foreign markets, opening outlets in Middle Eastern, European, and American cities, and they promote a 
particularly Turkish notion of tesettür fashion. Now a mature market, tesettür is a firmly established and globalized business sector in Turkey. However, the controversy surrounding it is not over. More orthodox critics continue to perceive new styles of covering as the degeneration and commodification of Islam (e.g., Barbarosoğlu 2005; Durmuş 2003). Others are more optimistic and regard these novel forms of tesettür as harbingers of a new phase of covering that is more in tune with the needs and desires of consumers. According to Perihan Mataraci and Serap Cebeci, two covered designers, tesettür fashion has been under the dominance of male businessmen who dress women according to their own understanding of religiously appropriate dress (Olgun 2005); most of the brand-name tesettür companies market clothes that are devoid of elegance, beauty, and aesthetics and force women to dress in a tasteless and uninspiring way (Olgun 2005). However, the new generation of covered women who demand fashionable, trendy, comfortable yet religiously appropriate clothes and the increasing number of female tesettür designers compel manufacturers to update their collections.

Secularists, on the other hand, are both skeptical and condescending about tesettür fashion. Their reactions are caught in the contradictory pull of religion, politics, and aesthetics. The adoption of the codes and practices of Western fashion by the so-called Islamists challenge the secular claim to fashion and modernity, rendering problematic the images of "fashionable" tesettürlü women. The images trigger ridicule, distrust, fear, or a mixture of all three. Two different sets of responses emerge in the secular media. One position denies that tesettürlü women have any genuine interest in fashion and being fashionable and perceives such consumption as a means to an end. Advocates of this position argue that the transformation in the ways tesettürlü women dress does not reflect a change in the ideological position, or a "softening" of religious politics; rather, it is a disguise. Many believe that fashionable styles of tesettür are tools for self-concealment, and beneath the facade of a trendily covered woman is the will to change the regime and introduce Islamic law in Turkey. ${ }^{4}$

The other position is less skeptical but more patronizing. It grants that covered women are interested in being fashionable and those who have money are concerned about status display. However, tesettür cannot be fashionable, and however hard tesettürlü women try to look trendy, elegant, and modern, they fail miserably. There are many articles in the secular media mocking the dressing styles of tesettürlü women and preaching to them about how they should dress to look more stylish. ${ }^{5}$ Most of these comments revolve around Emine Erdoğan, the wife of the prime minister, who became the first covered first lady in the Republic's history following the November 2002 elections. The secular media incessantly compare her clothes to the wives of other countries' leaders, judging them in terms of coordination, elegance, and fashionableness, and making fun of the tastelessness of her dressing style. ${ }^{6}$ Interestingly, 
political power does not easily translate into aesthetic competency, resulting in a continuous questioning of who wears what and how.

The secular media's concern with the aesthetics of covering, which often takes the form of style bashing, fits into what is referred to as a "spectacularist" consumption orientation in Turkey (Sandıkcı and Ger 2002). Spectacularist consumption is associated with the flamboyant and extravagant lifestyle of celebrities and is characterized by high fashionconsciousness, obsession with the body, addiction to brand-name products, and interest in night life. In the 1990s, paparazzi programs, called Televole in Turkish, which featured the lives of fashion, music, and sports stars, became very popular. Over time, a form of culture, which is heavily driven by conspicuous consumption, has developed around Televole programs. One feature of these programs is the appearance rating of celebrities. In every episode a couple of female celebrities are rated in terms of their overall look and beauty. The one who gets the lowest score is labeled the shabbiest lady of the week, while the one who gets the most points is announced as the most elegant lady of the week. Although no covered women are featured in these programs, it appears that judging style has been deeply ingrained in the secular media and, whether covered or not, a woman's appearance has become a matter of public scrutiny.

\section{Concluding Thoughts}

The tesettürlü woman is a political figure: she represents on the one hand, legislative power and governance, on the other hand, the clash between the secular ideology of the republic and so-called Islamist aspirations. However, she is also metaphorical, symbolizing the modern consumer who is never given but always socially and institutionally constructed. As we outlined, beginning in the 1980s, tesettürlü consumers emerged as a viable market segment and developed into a profitable one in the coming decades. A prominent feature of this market is its simultaneous and successful use of conventional and alternative tools of marketing. While advertisements, catalogs, fashion shows, and publicity acts are part of the tesettür marketers' arsenal, so are using tarikat connections and other networks. Tesettür is no longer a purely religious or purely political symbol but an industry that is substantial, transnational, complex, and evolving.

Tesettür fashion marketers and consumers partake in the global capitalist production and consumption regimes, and are subject to the economy of desire, seduction, and difference. The appeal and pursuit of a chic, elegant, and modern look, as observed in the narratives and practices of tesettür marketers and consumers, point to the universal attraction of the Western notion of fashion. The market for tesettür creates a social space of consumption that is marked by difference as 
well as similarity. Increasingly sophisticated advertising representations provide anti-discourses (see Born 1998) which deny or absent other, coexistent, and rival discourses that are articulated in the media and in society at large. We use the term "discourse" in the Foucauldian sense, including characteristic practices, social relations, institutions, technologies of self, and forms of knowledge. The Tesettür market and the fashion system provide a domain for an anti-discursive denial of the "threatening," "backward," and "ugly" image of the covered women. At the same time, this market and its fashion system produce the discourses that are in turn denied by secular institutions and media. These alternative cultural systems articulate their discourses and antidiscourses with their implicit connotations of distinction, difference and similarity; they resonate with collective psychic states just as much as with political and religious ideals.

Furthermore, this dynamic serves to embellish the focus on taste in a Bourdieuan sense. As the secular media emphasize tesettürlü women's lack of taste, the latter's concern with taste increases. The Islamic middle/ upper classes, perceived by themselves and others as lacking a particular type of cultural capital, become progressively keener to acquire it, especially as their economic capital increases. Thus, a repeated cycle of transformation emerges: the discourse of ugliness, backwardness, and threat propels attempts to beautify, to be modern and fashionable; these in turn change the process of acquiring, and the ways of dressing, and displaying. Then, new discourses and anti-discourses are articulated, including renewed criticisms and negotiations of taste; the cycle keeps repeating itself. As tastes change continuously, so do the construction and representation of tesettürlü women.

We have tried to show how taste and its transformations are framed by the global and local forces of capitalism, consumerism, and politics, as well as by the images of beauty and individualism. Whether in the form of Colgate and Indonesian misvak toothpaste, newspaper cartoons, or reactions towards fashion shows, global-local worlds of markets and politics (re)construct and represent identities dynamically.

\section{Notes}

1. The term "Islamist" (Íslamcı) is commonly used as a derogatory label to denote affiliation to political and revolutionary Islam.

2. Sunna refers to established religious norms built on the Prophet's example.

3. Since 1995, Tekbir Giyim has introduced dresses named after the former prime minister Tansu Çiller, former MPs Merve Kavakçı and Nesrin Ünal, the wives of the current president Semra Sezer and the current prime minister Emine Erdoğan. 


\section{Figure 6}

Cumhuriyet newspaper, cartoon by Mustafa Bilgin, August 11 2005.

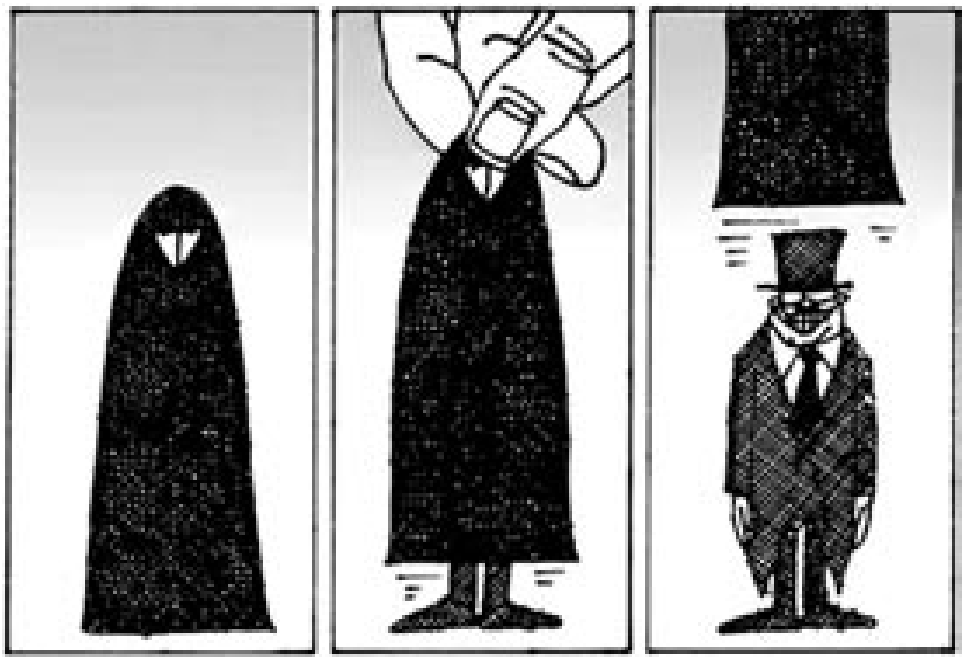

4. A representative of this perspective is Cumburiyet newspaper, which is known for its hard-line secular position. The paper publishes comments, news stories, and articles that criticize the Islamists and the government for disguising their real ambition, which is to destroy the Republic and transform Turkey into a country ruled by Islamic law. Figure 6 shows an example typifying the distrust and fear. The cartoon suggests that the covered woman wearing a black chador, which is perceived as the symbol of Islamic revolution, is the tool of fundamentalist politicians.

5. For example, in an interview published in a high-circulation secular newspaper Mehmet Şevki Eygi, a popular Islamist intellectual and writer, claims that covered women "use unbearable colors in their clothing, such as sheer pink, dress extremely unstylishly," and "are dressed as if they were servants" (quoted in Arman 2004a).

6. In May 2004, the prime minister and his wife visited Greece. The visit became notorious not for its political consequences but for the clothing style of Ms Emine Erdoğan. Pictures of her struggling to walk on the Acropolis wearing high heels while her counterpart, the wife of the Greek prime minister, walked comfortably in her sneakers circulated in the secular media. In one of the commentaries, Arman remarks that "the most unsuitable thing to wear while climbing up the Acropolis is high-heel boots. When you wear them, of course somebody has to hold your hand; otherwise you cannot walk. Moreover, you look comical" (2004b). She further claims "the outfit she has put on is extraordinarily out-of-fashion" and urges Emine Erdoğan to get professional help in choosing her clothes and accessories (2004b). 


\section{References}

Akta, Pınar. 2002. “Tekbir Giyim Sunar: Emine Erdoğan 2003!” Milliyet (November 13): 8.

Arman, Ayşe. 2004a. "Mehmet Şevket Eygi'ye Göre Tesettürlü Kadınlar Rüküş.” Hürriyet Pazar (August 29): http://www.haberx. com/n/148087/mehmet-sevket-eygiye-gore-tesetturlu.htm.

Arman, Ayşe. 2004b. "Emine Erdoğan'ı Bir Başkası Giydirmeli." Hürriyet (May 10): http://hurarsiv.hurriyet.com.tr/goster/haber.aspx ?id=224396\&yazarid $=12$.

Atay, Ayca. 2003. “Islami Burjuvazi Geliyor.” Milliyet (June 8): 19.

Barbarosoğlu, Fatma Karabiyık. 2005. “Tesaettür Defilelerinde 'Öteki' Üzerinden Şov.” Yeni Şafak (November 25): http://www.yenisafak. com.tr/diziler/basortu/basortu03.html.

Berger, John. 1972. Ways of Seeing. London: BBC.

Born, Georgina. 1998. "Anthropology, Kleinian Psychoanalysis, and the Subject in Culture." American Anthropologist 100(2): 373-86.

Davila, Arlene. 2001. Latinos Inc.: The Making and Marketing of a People. Berkeley, CA: University of California Press.

Demir, Ömer, Mustafa Acar and Metin Toprak. 2004. "Anatolian Tigers or Islamic Capital: Prospects and Challenges.” Middle Eastern Studies 40(6): 166-88.

Durmuş, Mehmed. 2003. "İslami Usullerde Teşhircilik Yapılır.” İktibas 22(294): http://www.iktibas.info/dergi/2003/haziran/dusunce.htm.

Engin, Bora. 2004. “Tessettur Modasi Zincirlerini Kirdi.” Vatan (May 18): http://www.vatanim.com.tr/root.vatan?exec=haberdetay \&News $\mathrm{id}=28020 \&$ Categoryid $=7$.

Ersoy, Meltem. 2005. "Colgate: Misvak Özlü Diş Macunu Yaptık, Lider Oluruz." Milliyet (July 13): http://www.hurriyetim.com.tr/ haber/0,sid 4@tarih 2005-07-13-t@nvid 603536,00.asp.

Goffman, Erving. 1979. Gender Advertisements. London: Macmillan.

Goldman, Robert. 1992. Reading Ads Socially. London: Routledge.

Göle, Nilüfer. 2000. "Snapshots of Islamic Modernities.” Daedalus 129(1): 91-117.

—. 2002. "Islam in Public: New Visibilities and New Imaginaries." Public Culture 14(1): 173-90.

Kas, Nilufer. 1999. “Tesettürde Aç-Kapa Nesrin Modası.” Tempo 42(619): 54-6.

Kılıcbay, Barış and Mutlu Binark. 2002. "Consumer Culture, Islam and the Politics of Lifestyle.” European Journal of Communication 17(4): 495-511.

Leiss, William, Stephen Klein and Sut Jhally. 1986. Social Communication in Advertising. Toronto: Methuen.

Mittelstaedt, John. 2002. "A Framework for Understanding the Relationships between Religions and Markets.” Journal of Macromarketing 22(1): 6-18. 
Mort, F. "Boy's Own? Masculinity, Style and Popular Culture." In R. Chapman and J. Rutherford (eds) Male Order: Unwrapping Masculinity, pp. 193-224. London: Lawrence and Wishart.

Navaro-Yashin, Yael. 2002. "The Market for Identities: Secularism, Islamism, Commodities." In Deniz Kandiyoti and Ayse Saktanber (eds) Fragments of Culture: The Everyday of Modern Turkey, pp. 221-53. London: I. B. Tauris.

Olgun, Ayşe. 2005. "Kadın Modacılar Erkek Patronlara Kazan Kaldırdı." Yeni Şafak September 20: 7.

Özcan, Zafer and Ayşe Atlı. 2005. "Tesettur de Modaya Kapıldı." Aksiyon 10(573): http://www.aksiyon.com.tr/detay.php?id=19344.

Öniş, Ziya. 1991. "Political Economy of the 1980s: Anatomy of Unorthodox Liberalism.” In M. Heper (ed.) Strong State and Economic Interest Groups: The Post-1980 Experience, pp. 27-40. Berlin and New York: de Gruyter.

Polanyi, K. 1992. “The Economy as an Instituted Process.” In M. Granovetter and R.

Swedberg (eds) The Sociology of Economic Life, pp. 31-50. Boulder, CO: Westview Press.

Sandıkcı, Özlem and Güliz Ger. 2001. "Fundamental Fashions: The Cultural Politics of the Turban and the Levi's." Advances in Consumer Research 28: 146-50.

— and — 2002. "In-Between Modernities and Postmodernities: Investigating Turkish Consumptionscape." Advances in Consumer Research 29: 465-70.

— and - 2005. "Aesthetics, Ethics and Politics of the Turkish Headscarf.” In S. Kuechler and D. Miller (eds) Clothing as Material Culture, pp. 61-82. Oxford: Berg.

Schroeder, Jonathan and Detlev Zwick. 2004. "Mirrors of Masculinity: Representation and Identity in Advertising Images." Consumption, Markets and Culture 7(1): 21-52.

Sinclair, John. 1987. Image Incorporated: Advertising as Industry and Ideology. London and New York: Croom Helm.

Slater, Don and Fran Tonkiss. 2001. Market Society. Cambridge: Polity.

Williamson, Judith. 1978. Decoding Advertisements: Ideology and Meaning in Advertising. London: Marion Boyars.

Zukin, Sharon and Paul Dimaggio (eds). 1990. Structures of Capital: The Social Organization of Economy. New York: Cambridge University Press. 